\title{
The Macroeconomic Effects of Fiscal Policy in Portugal: a Bayesian SVAR Analysis
}

\author{
António Afonso ${ }^{\#}$ and Ricardo M. Sousa
}

December 2010

\begin{abstract}
With a new quarterly dataset we estimate a Bayesian Structural Autoregression model and a Fully Simultaneous System approach to analyze the macroeconomic effects of fiscal policy. Results show that positive government spending shocks, in general, have a negative effect on real GDP; lead to "crowding-out" effects of private consumption and investment; have a persistent and positive effect on the price level and a mixed impact on the average financing cost of government debt. Explicitly considering the government debt dynamics in the model is also important. A VAR counter-factual exercise confirms that unexpected positive spending shocks create relevant "crowdingout" effects.
\end{abstract}

Keywords: B-SVAR, Fully Simultaneous System, fiscal policy, debt dynamics, Portugal.

JEL classification: E37, E62, H62, G10.

\footnotetext{
* We are grateful to Ad van Riet, to participants to the $4^{\text {th }}$ Meeting of the Portuguese Economic Journal, and to an anonymous referee for helpful comments. The opinions expressed herein are those of the authors and do not necessarily reflect those of the ECB or the Eurosystem.

${ }^{\#}$ European Central Bank, Directorate General Economics, Kaiserstraße 29, D-60311 Frankfurt am Main, Germany. ISEG/TULisbon - Technical University of Lisbon, Department of Economics; UECE Research Unit on Complexity and Economics; R. Miguel Lupi 20, 1249-078 Lisbon, Portugal. UECE is supported by FCT (Fundação para a Ciência e a Tecnologia, Portugal), financed by ERDF and Portuguese funds. E-mails: antonio.afonso@ecb.europa.eu, aafonso@iseg.utl.pt.

${ }^{\$}$ University of Minho, Department of Economics and Economic Policies Research Unit (NIPE), Campus of Gualtar, 4710-057 - Braga, Portugal; London School of Economics, Financial Markets Group (FMG), Houghton Street, London WC2 2AE, United Kingdom. E-mails: rjsousa@eeg.uminho.pt; rjsousa@alumni.lse.ac.uk.
} 


\section{Introduction}

In the last twenty years, public spending control has been a major problem in Portugal. The gains from the drop in interest rates and, consequently, in the interest payments on the outstanding government debt were not accompanied by a sustained consolidation of public finances. Moreover, the episodes of fiscal improvement that occurred in the 1980s and in the 1990s have been short-termed and mostly not successful. Following the introduction of the Stability and Growth Pact (SGP), Portugal was the first country in the Economic and Monetary Union to breach the 3\% of GDP reference value for the government deficit in 2001. Consequently, it became subject to the Excessive Deficit Procedure (EDP) in 2002, a situation that occurred again in 2005.

Therefore, given past performance and outcomes, it seems fair to say that after entering the European Union (EU) in 1986, joining the Exchange Rate Mechanism (ERM) of the European Monetary System (EMS) in 1992 and entering EMU in January 1999, Portugal's fiscal track record could have been better.

In this context, the evaluation of the effects of fiscal policy on economic activity in Portugal becomes relevant and is the major goal of this paper. Additionally, we look at its impact on the composition of GDP, therefore, analyzing potential "crowding-out" effects on private consumption and private investment.

Fiscal policy shocks are identified using a recursive partial identification scheme $^{1}$ and we assess the posterior uncertainty of the impulse-response functions by estimating a Bayesian Structural Vector Autoregression (B-SVAR) model. We also account for the automatic response of fiscal policy to the economic activity, and use a Fully Simultaneous System approach in line with the works of Blanchard and Perotti (2002), Leeper and Zha (2003) and Sims and Zha (1999, 2006). In addition, we consider

\footnotetext{
${ }^{1}$ Christiano et al. (2005) identify the monetary policy shock using the same procedure.
} 
the response of fiscal variables to the level of the government debt following Favero and Giavazzi (2007) and Afonso and Sousa (2009a).

Another important contribution of the paper is the use of a set of quarterly fiscal data, which we build by drawing on the higher frequency (monthly) availability of fiscal cash data. This allows us to identify more precisely the effects of fiscal policy.

The findings of this paper can be summarized as follows. On the one hand, government spending shocks: (i) have a negative effect on real GDP; (ii) generate substantial "crowding-out" effects and lead to a fall in both private consumption and private investment; (iii) have a persistent and positive impact on the price level; and (iv) have mixed impacts on the average cost of refinancing the debt. Therefore, and from a policymaking perspective, increasing government spending does not emerge as an obvious instrument to help fostering economic activity.

On the other hand, government revenue shocks: (i) have a negative impact on GDP; (ii) crowd-out private consumption and private investment, although the response emerges with a lag of about four quarters; and (iii) is normally followed by a somewhat less disciplined fiscal policy.

The consideration of the feedback from government debt makes the effects of fiscal policy on (long-term) interest rates and GDP more persistent and these variables are also more responsive to the shocks. Moreover, the results do not seem to support the existence of a significant stabilizing response of the budget balance to the debt level. In fact, there is only weak evidence suggesting that: (i) government spending falls when the debt-to-GDP ratio is above its mean (in particular, in the period 1979:1-1993:3); and (ii) government revenue increases when the debt-to-GDP ratio is above its mean (namely, in the period 1993:4-2007:4, that is, after the Maastricht Treaty). Therefore, there was a possible Ricardian behaviour after the beginning of the 1990s, although the 
past fiscal stabilization attempts have been mostly biased towards increases in government revenue, without tackling sufficiently the spending side. Moreover, and as we will see below, the breaching of the SGP by Portugal in 2002 cannot be disconnected from such past fiscal responses. Finally, a VAR counterfactual exercise shows that unexpected increases in government spending lead to important "crowdingout" effects.

The rest of the paper is organized as follows. Section two reviews the related literature. Section three presents fiscal developments in Portugal. Section four explains the empirical strategies used to identify the effects of fiscal policy shocks. Section five describes the data and provides the empirical analysis. Section six concludes.

\section{Literature Review}

Despite the large literature on the impact of monetary policy on economic activity, the importance of fiscal policy for economic stabilization has received less attention. This section provides a brief review of the existing evidence of the effects of fiscal policy on GDP, the aggregate price level and the composition of output, that is, private consumption and private investment.

For the U.S., different approaches have been used in the identification of the fiscal policy shock. The "narrative approach" developed by Ramey and Shapiro (1998) isolates political events and finds that, after a brief rise in government spending, durables consumption falls while nondurable consumption displays a small decline. Fatás and Mihov (2001) use a Cholesky ordering and show that increases in government expenditures are expansionary, but lead to important changes in the composition of output in the form of an increase in private investment that more than compensates for the fall in private consumption. Blanchard and Perotti (2002) identify the automatic 
response of fiscal policy by using information about the elasticity of fiscal variables, and find that fiscal shocks are expansionary, have a positive effect on private consumption, and a negative impact on private investment. More recently, Mountford and Uhlig (2009) relying on sign restrictions for the fiscal impulse-response functions find a negative effect in residential and non-residential investment for the U.S..

At the international level, the evidence is scarce due to the limited availability of quarterly public finance data. Perotti (2004) finds that fiscal policy leads to no response of private investment and a relatively large and positive effect on private consumption in a set of five countries (Australia, Canada, Germany, the U.S. and the U.K.). For France, Biau and Girard (2005) find a positive effect on both private consumption and private investment. For Spain, De Castro and Hernández de Cos (2008) show that a positive spending shock lead to higher inflation and lower output in the medium and long-term, but can be expansionary in the short-term. Heppke-Falk et al. (2006) and Giordano et al. (2007) find that government spending has expansionary effects on both output and private consumption for, respectively, Germany and Italy. Afonso and Sousa (2009a, 2009b) show that, for the U.S., the U.K., Germany and Italy, quarterly fiscal policy shocks have important macroeconomic effects while also impacting on housing and stock prices. In addition, Burriel et al. (2010), using a quarterly standard SVAR, report that expenditure shocks are more persistent in the US than in the euro area, while the negative response from net tax increases is shorter lived in the euro area.

As can be inferred from the abovementioned studies, data availability - in particular, high frequency data -, remains a major drawback in the literature on fiscal policy. Therefore, we try to overcome this issue, by building also a fiscal quarterly dataset for Portugal. 


\section{Recent Fiscal Developments in Portugal}

According to Afonso and Claeys (2008), the main reasons for the three initial breaches of the SGP in 2002 and 2003 were expenditure rises in France and Portugal, while large revenue reductions unmatched by expenditure cuts in Germany pushed the budget deficit beyond 3 per cent of GDP. Therefore, this evidence, points to some difficulties related to expenditure control in Portugal.

In 2003 and 2004, Portugal used sizable temporary measures, amounting respectively to 2.5 and 2.3 per cent of GDP, in order to keep the budget deficit below the 3 per cent limit. Overall, such temporary measures implemented in the 2002-2004 period, added up to 6.2 per cent of GDP. ${ }^{2}$

The adoption of temporary corrective measures, even if it prevented the budget deficit from going above the 3 per cent limit, did not address the structural factors underlying Portuguese fiscal imbalances. Additionally, after the 2002 EDP, the consolidation strategy also included an increase in the standard VAT rate (from 17 to 19 per cent, which was again raised to 21 per cent in July 2005, but cut back to 20 per cent in July 2009), while primary spending continued rising. ${ }^{3}$

A second EDP was started in June 2005 and was abrogated in June 2008. Among the several measures then proposed and implemented by the authorities to control primary spending, one can mention as some of the more structurally oriented ones, for instance, the revision of the civil servants' pension schemes, and the reform of the health care sector. ${ }^{4}$ Interestingly, both EDP episodes that occurred in Portugal were characterised by fiscal easing, but while the 2001 episode was coupled with more

2 For instance, pension funds transfers from public sector enterprises to the civil servants pension system in 2004; securitization of tax credits in 2003; and tax amnesty in 2002.

3 Guichard and Leibfritz (2006) also survey the reasons for the non-successful fiscal adjustment in the period 2002-2004.

4 Since 2002, some public hospitals have been transformed into public corporations, to increase efficiency and decrease costs in the National Health Service (NHS). However, Afonso and Fernandes 
favourable monetary conditions, in the 2005 episode monetary conditions were more stringent (see Figure 1).

\section{[Figure 1]}

After entering the EU in 1986, both inflation and interest rates in Portugal decreased steadily and converged towards the lower levels that were more common in other countries already in the EU. This was an obvious benefit from entering the EU, with capital markets adjusting expectations vis-à-vis Portugal, which also allowed for better and more stable sovereign debt ratings attributed to the country.

Regarding the past experiences in terms of fiscal consolidations, fiscal episodes can be identified based on the change in the cyclically adjusted primary budget balance. For this purpose, Afonso (2010) determines for the EU countries the periods when the change in the primary cyclically adjusted budget balance is at least 2 percentage points (pp) of GDP in one year or at least $1.5 \mathrm{pp}$ points on average in the last two years. For the case of Portugal, two episodes of fiscal expansion (1980-1981, 2005) and three episodes of fiscal contraction can be reported (1982-83, 1986, and 1992). ${ }^{5}$ Following such approach, we can also observe an additional fiscal contraction in 2006-2007.

The abovementioned fiscal consolidation episodes were, on the one hand shorttermed, and on the other hand mostly unsuccessful. During the 1982-83 consolidation both expenditures and revenues increased, as a share of GDP, while the debt-to-GDP ratio kept on increasing at the same time. ${ }^{6}$ In the 1986 consolidation (the year of Portugal's entry in the EU), one observes a certain stabilization of revenues as a share of GDP, a decrease in the expenditure-to-GDP ratio, and also a decrease in the debt ratio in

(2008) did not find, for the period 2000-2005, significant differences in efficiency between hospitals with public corporations status and Administrative Public Sector hospitals.

5 Blanchard (2007) argues that discretionary fiscal policy was expansionary in Portugal in 1995-2001.

6 The Portuguese Escudo effective exchange rate faced a devaluation of 17 and 23 per cent respectively in 1982 and 1983, while Portugal undertook an IMF stabilisation programme. 
the following three years. Additionally, the primary balance was also in surplus for the first time in thirteen years.

Finally, the 1992 episode was very short-termed, taking place in a difficult environment, following revenue and expenditure increases with the debt ratio rising immediately afterwards. ${ }^{7}$ Moreover, the 1993 economic downturn in Europe did not play in favour of prolonging the consolidation, with the primary spending-to-GDP ratio increasing more significantly in that year. Indeed, a commonly known feature of fiscal policies in Portugal in the past has been the pro-cyclical behaviour of primary spending, which contributed to prevent the implementation of successful fiscal consolidations (see, for instance, Pina, 2004). Such pro-cyclical behaviour would again be present in 2001, with the budget deficit going once more above the 3 per cent limit.

\section{Modelling Strategies}

\subsection{The Bayesian Structural VAR}

The first methodology used to analyze the macroeconomic effects of fiscal policy consists on the estimation of the following Structural VAR (SVAR)

$$
\begin{gathered}
\underbrace{\Gamma(\boldsymbol{L}) \boldsymbol{X}_{\boldsymbol{n} \times 1}^{\boldsymbol{X}_{t}}}_{\boldsymbol{n} \times \boldsymbol{n}}+\gamma_{i} \boldsymbol{d}_{t-1}=\Gamma_{0} \boldsymbol{X}_{t}+\Gamma_{1} \boldsymbol{X}_{t-1}+\ldots+\gamma_{i} \boldsymbol{d}_{t-1}=\boldsymbol{c}+\varepsilon_{t} \\
d_{t}=\frac{1+i_{t}}{\left(1+\pi_{t}\right)\left(1+\mu_{t}\right)} d_{t-1}+\frac{G_{t}-T_{t}}{P_{t} Y_{t}} \\
v_{t}=\Gamma_{0}^{-1} \varepsilon_{\mathrm{t}},
\end{gathered}
$$

7 Additionally, in 1992 and in 1993 privatisation revenues amounting respectively to 1.5 and 0.4 per cent of GDP were used for debt redemption. Coincidentally Portugal entered the ERM in April 1992, precisely the year were several currencies in the ERM system undergone speculative attacks, forcing both the Italian Lira and the British Pound out of the system after September 2002. 
where $\varepsilon_{t} \mid X_{s}, s<t \sim \mathrm{N}(0, \Lambda), \Gamma(L)$ is a matrix valued polynomial in positive powers of the lag operator $L, n$ is the number of variables in the system, $\varepsilon_{t}$ is the fundamental economic shock, and $v_{t}$ is the VAR innovation.

Equation (2) describes the government's budget constraint, and $i_{t}, G_{t}, T_{t}, \pi_{t}, Y_{t}$, $P_{t}, \mu_{t}$ and $d_{t}$ represent, respectively, the average cost of debt refinancing, government primary spending, government revenues, inflation, GDP, price level, real growth rate of GDP, and the debt-to-GDP ratio at the beginning of the period $t$.

The specification follows Favero and Giavazzi (2007) in that we include the government debt dynamics, namely, by appending the non-linear budget identity to the VAR.

We use a recursive identification scheme and characterize fiscal policy as follows:

$$
\begin{aligned}
& G_{t}=f\left(\Omega_{t}\right)+\varepsilon_{t}^{G} \\
& T_{t}=g\left(\Omega_{t}\right)+\varepsilon_{t}^{T}
\end{aligned}
$$

where, $G_{t}$ is the government primary spending, $T_{t}$ is the government revenue, $f$ and $g$ are linear functions, $\Omega_{t}$ is the information set, and $\varepsilon_{t}^{G}$ and $\varepsilon_{t}^{T}$ are, respectively, the government spending shock and the government revenue shock, which are orthogonal to the elements in $\Omega_{t}$.

We assume that the variables in $X_{t}$ can be separated into 2 groups: (i) a subset of $n_{l}$ variables, $X_{1 t}$ (GDP, GDP deflator, consumption, investment, cost of debt), whose contemporaneous values appear in the policy function and do not respond contemporaneously to the fiscal policy shocks; and (ii) the policy variables in the form of government primary expenditure, $G_{t}$, and/or government revenue, $T_{t}$. 
Therefore, the recursive assumptions can be represented by $\boldsymbol{X}_{t}=\left[\boldsymbol{X}_{1 t}, \boldsymbol{T}_{\boldsymbol{t}}, \boldsymbol{G}_{t}\right]$ and

$$
\Gamma_{0}=\left[\begin{array}{cc}
\underbrace{\gamma_{11}}_{n_{1} \times n_{1}} & \underbrace{0}_{n_{1} \times 2} \\
\underbrace{\gamma_{21}}_{2 \times n_{1}} & \underbrace{\gamma_{22}}_{2 \times 2}
\end{array}\right] .
$$

This approach is also used by Christiano et al. (2005) in the context of identification of unexpected variation in monetary policy. Finally, we follow Sims and Zha (1999) and assess the posterior uncertainty about the impulse-response functions by using a Monte Carlo Markov-Chain (MCMC) algorithm.

\subsection{The Fully Simultaneous System Approach}

The second methodology used in the identification of fiscal policy shocks relies on a Fully Simultaneous System of Equations approach in a Bayesian framework.

We start by considering the structural VAR represented by (1), (2) and (3). The set of variables included in the system is $\boldsymbol{X}_{t}=\left[\boldsymbol{G}_{t}, \boldsymbol{T}_{t}, \boldsymbol{Y}_{t}, \boldsymbol{P}_{t}, \boldsymbol{i}_{t}\right], G_{t}$, the government primary expenditures, $T_{t}$, the government revenue, $Y_{t}$, the GDP, $P_{t}$, the GDP deflator, and $i_{t}$, the average cost of debt financing.

The economy is divided into two sectors: a public and a production sector. The public sector - that allows for simultaneous effects -, comprises the equations for government primary spending and government revenue, and links them with the log real GDP, the GDP deflator, and the average cost of financing debt. The production sector consists of log real GDP, and the GDP deflator.

Additionally, we follow Blanchard and Perotti (2002) and Perotti (2004), and assess the automatic response of taxes and government primary spending to economic 
activity by computing the elasticity of government revenue and spending to macroeconomic variables.

The restrictions on the matrix of contemporaneous effects, $\Gamma_{0}$, that allow us to identify the fiscal policy shock can be defined as

$$
\Gamma_{0}=\left[\begin{array}{ccccc}
\gamma_{11} & \gamma_{12} & -\xi_{\boldsymbol{G}, \boldsymbol{Y}} \cdot \gamma_{11} & -\xi_{\boldsymbol{G}, \pi} \cdot \gamma_{11} & -\xi_{\boldsymbol{G}, \boldsymbol{i}} \cdot \gamma_{11} \\
\gamma_{21} & \gamma_{22} & -\xi_{\boldsymbol{T}, \boldsymbol{Y}} \cdot \gamma_{22} & -\xi_{\boldsymbol{T}, \pi} \cdot \gamma_{22} & -\xi_{\boldsymbol{T}, i} \cdot \gamma_{22} \\
0 & 0 & \gamma_{33} & 0 & 0 \\
0 & 0 & \gamma_{43} & \gamma_{44} & 0 \\
0 & 0 & \gamma_{53} & \gamma_{54} & \gamma_{55}
\end{array}\right]\left[\begin{array}{l}
\boldsymbol{G}_{\boldsymbol{t}} \\
\boldsymbol{T}_{\boldsymbol{t}} \\
\boldsymbol{Y}_{\boldsymbol{t}} \\
\boldsymbol{P}_{\boldsymbol{t}} \\
\boldsymbol{i}_{\boldsymbol{t}}
\end{array}\right],
$$

where the parameters $\xi_{i j}$ represent the elasticity of the fiscal policy instrument $i$ with respect to the macroeconomic variable $j$. Table 1 reports the elasticities used in the identification procedure.

Table 1 - Elasticities of Government Spending and Revenue.

\begin{tabular}{cccccc}
\hline \multicolumn{3}{c}{ Elasticities of Government Spending } & \multicolumn{3}{c}{ Elasticities of Government Revenue } \\
\hline$\xi_{G, Y}$ & $\xi_{G, \pi}$ & $\xi_{G, i}$ & $\xi_{T, Y}$ & $\xi_{T, \pi}$ & $\xi_{T, i}$ \\
\hline 0 & -0.5 & 0 & 1.6 & 1.25 & 0 \\
\hline
\end{tabular}

Note: The estimates of the elasticities are based on Girouard and André (2005), although the results are not sensitive to changes in parameters.

Finally, we use Bayesian inference to assess the posterior uncertainty about the impulse-response functions in the Fully Simultaneous system of equations as in Leeper and Zha (2003), and Sims and Zha (1999, 2006), and consider a Monte Carlo Importance Sampling Normalized Weights algorithm.

\section{Empirical analysis}

\subsection{Data}

This section provides a summary description of the data employed in the empirical analysis. A detailed description is provided in the appendix. All variables are 
in natural logarithms unless stated otherwise and the data covers the period 1978:12007:4.

In the recursive partial identification scheme, the variables that are predetermined with respect to fiscal policy innovations are the GDP, private consumption, private investment, and GDP deflator. To these variables, we add the average cost of government debt financing (or the yield to maturity of long-term government bonds). ${ }^{8}$ As measure of the fiscal policy instruments, we use either the government expenditures (and government revenues are included in $X_{1 t}$ ) or the government revenues (in which case, government expenditures are included in $X_{1 t}$ ).

In the Fully Simultaneous System approach, we restrict the set of variables to the GDP, GDP deflator, the average cost of debt financing and the fiscal policy instruments. In both frameworks, we include a constant (or quarterly seasonal dummies), and the government debt-to-GDP ratio in the set of exogenous variables. All variables were deflated by the GDP deflator $(2000=100)$.

Figure 2 plots the average debt cost servicing and the nominal (annualized) GDP growth. It shows that Portugal, in general, has moved from a situation where nominal GDP growth exceeded the cost of financing the debt to a situation where the converse has been true.

In addition, Figure 3 displays the observed debt-to-GDP ratio and the implicit debt-to-GDP ratio, that is, the one that emerges from the government debt's feedback. As can be seen, the implicit series for the debt-to-GDP ratio tracks pretty well the actual series.

\section{[Figure 2]}

\section{[Figure 3]}

8 The average government debt cost is obtained by dividing the net interest payments in $t$ by the government debt at time $\mathrm{t}-1$. 
Finally, the quarterly series of government spending and revenues are computed using the monthly Central Government's cash data.

\subsection{Results}

\subsubsection{The Bayesian Structural VAR}

We start by estimating a B-SVAR model that does not include the feedback from government debt, that is, where equation (2) is not considered. Then, we compare the results with the ones that emerge from estimating specifications (1), (2), and (3).

Figure 4 shows the impulse-response functions to a fiscal policy shock. The solid line refers to the median response when the VAR is estimated without the feedback from government debt, and the dashed lines are, respectively, the median response and the 68 per cent posterior confidence intervals from the VAR estimated by imposing the debt dynamics. The confidence bands are constructed using a Monte Carlo Markov-Chain (MCMC) algorithm based on 50000 draws.

\section{[Figure 4]}

Figure 4a displays the impulse-response functions of all variables in $X_{t}$ to a positive shock in government primary spending. In the case we do not include the debt feedback, it can be seen that government spending declines steadily following the shock, and the effect roughly vanishes after eight quarters. The effects on GDP are negative and reveal that government spending has a strong "crowding-out" effect on the private sector. In fact, both private consumption and private investment fall after the shock. In particular, a $6 \%$ shock in government spending leads to a $0.5 \%$ fall in GDP six quarters ahead. Similarly, private consumption falls by $0.6 \%$, while the effects in private investment are more pronnounced (a fall of $1 \%$ at the horizon of six quarters). These results are in line with the works of Giavazzi and Pagano (1990) and Alesina and 
Ardagna (1998) who uncovered the presence of "non-Keynesian effects" (i.e., negative spending multipliers) during large fiscal consolidations.

In addition, there is a positive effect on the average cost of debt that reaches its peak after six quarters. The price level is also impacted persistently and positively by the shock in government spending. Finally, the results suggest that after a government spending shock, there is an increase in government revenue which is, however, small. Therefore, this suggests that an expansion of government spending is associated with a episode of fiscal deterioration.

When we include the debt dynamics in the model, the effects of a government spending shock on the average cost of debt become somewhat larger while the impact on GDP is marginally smaller. Additionally, investment consistently falls much more than before and the positive impact on the price level is attenuated by the feedback from government debt.

Figure $4 \mathrm{~b}$ shows the impulse-response functions to a positive shock in government revenue. The results suggest that government revenue declines after the shock which erodes in about eight quarters. The effects on GDP, private consumption and private investment are slightly positive over the four quarters following the shock, but they quickly mean revert and become negative. In fact, a 5\% shock in government revenue has its maximum impact on GDP $(0.3 \%)$, private consumption $(0.2 \%)$ and private investment $(0.7 \%)$ at the four quarters horizon, after which the effects erode and change sign. These results are in accordance to the findings of Giavazzi et al. (2000) who show that a rise of taxes can have a positive impact on private consumption in periods of fiscal consolidation. In contrast, the price level falls for about four quarters, then recovers, and becomes positive. This evidence is closely related to the reaction of government spending, which increases after the shock. In fact, an increase in 
government revenue is followed by a somewhat less disciplined fiscal policy and, as a result, there is a deterioration of the fiscal balance. This also seems to be the reason for the positive impact on the average cost of debt, implying that the authorities should be aware of such market reactions when implementing fiscal policy.

In terms of the forecast error-variance decomposition of the variables in the system to a shock in government spending or revenue (not shown for space sake), both shocks account for a large fraction of their own forecast-error variance decomposition, and play a negligible role for the remaining variables.

\subsubsection{The Fully Simultaneous System Approach}

Figure 5 displays the impulse-response functions to a fiscal policy shock in the Fully Simultaneous System approach. The solid line refers to the median response when the system is estimated without imposing the dynamics from government debt, and the dashed lines are, respectively, the median response and the 68 per cent posterior confidence intervals from the system estimated by including the feedback from government debt. The confidence bands are constructed using an Importance Sampling Normalized Weights algorithm based on 50000 draws.

\section{[Figure 5]}

Figure 5a displays the impulse-response functions of all variables to a positive shock in government primary spending. When we do not take into account the feedback from government debt, one can see that the shock to government spending erodes after four quarters. The effects on GDP are negative - therefore, denoting the presence of "non-Keynesian effects" - and the trough is reached after four quarters. At this horizon, a $3 \%$ shock in government spending leads to a fall of GDP of between $0.2 \%$ and $0.4 \%$. 
As in the case of the recursive partial identification scheme, the impact on the price level is positive, although somewhat less persistent, and there is also a fiscal deterioration as government revenues fall after the shock. In contrast, there is a negative effect on the average cost of debt that reaches its trough after six quarters.

When the debt dynamics is included in the model, the effects of a government spending shock: (i) on GDP are smaller; (ii) become larger in the case of the average cost of debt; and (iii) are somewhat smaller for the price level.

Figure $5 \mathrm{~b}$ shows the impulse-response functions to a positive government revenue shock. The (negative) response of GDP is not lagged, despite being gradual. The trough is achieved after eight quarters, where a 3\% shock in government revenue reduces GDP by about $0.4 \%$. Similarly, the price level does not react with a lag but gradually increases instead, and the effect is very persistent. These pieces of evidence can not be separated from the behaviour of government spending, which increases after the shock, therefore, suggesting a deterioration of public finances. In fact, the average cost of debt is positively impacted, reflecting the less disciplined fiscal policy.

\subsection{Fiscal shocks and government debt feedback}

In this sub-section, we consider the potential debt feedback by estimating the following structural VAR:

$$
\begin{aligned}
& \Gamma_{0} X_{t}+\Gamma_{1} X_{t-1}+\ldots+\gamma_{i}\left(d_{t-1}-d^{*}\right)=c+\varepsilon_{t}, \\
& d_{t}=\frac{1+i_{t}}{\left(1+\pi_{t}\right)\left(1+\mu_{t}\right)} d_{t-1}+\frac{G_{t}-T_{t}}{P_{t} Y_{t}} .
\end{aligned}
$$

Specification (8) is suggested by Bohn (1998) who considers a fiscal reaction function in which $d^{*}$ is the unconditional mean of the debt ratio. In the same spirit, Romer and Romer (2007) suggest that the effect of a tax shock on output may be 
conditional on the government's aim to stabilize the debt. Therefore, we model the target level of the debt as a constant on the basis of the evidence of stationarity of $d$.

The estimated coefficients on $\left(d_{t^{-1}}-d^{*}\right)$ in the structural equations of the SVAR (government spending and government revenue) are reported in Table 2. We consider the full sample and two sub-samples: 1979:1 - 1993:3, corresponding to the period before the Maastricht Treaty entered into force; and 1993:4 - 2007:4, thereafter.

\begin{tabular}{|c|c|c|c|}
\hline & & $\mathrm{T}_{\mathrm{t}}$ & $\mathrm{G}_{\mathrm{t}}$ \\
\hline \multirow{3}{*}{$\left(\mathrm{d}_{\mathrm{t}-1}-\mathrm{d}^{*}\right)$} & $\begin{array}{c}1979: 1-2007: 4 \\
(\mathrm{~N}=116)\end{array}$ & $\begin{array}{l}-0.001 \\
(0.001)\end{array}$ & $\begin{array}{c}0.000 \\
(0.002)\end{array}$ \\
\hline & $\begin{array}{c}1979: 1-1993: 3 \\
(\mathrm{~N}=59)\end{array}$ & $\begin{array}{c}-0.008^{* * * *} \\
(0.002)\end{array}$ & $\begin{array}{l}-0.005^{*} \\
(0.003)\end{array}$ \\
\hline & $\begin{array}{c}1993: 4-2007: 4 \\
(\mathrm{~N}=57)\end{array}$ & $\begin{array}{l}0.006^{*} \\
(0.03)\end{array}$ & $\begin{array}{c}0.002 \\
(0.004)\end{array}$ \\
\hline
\end{tabular}

Note: standard errors in brackets.

$*, * *, * * *$ - statistically significant respectively at the $10 \%, 5 \%$, and $1 \%$ levels.

In general, the results do not show a significant response of revenue and primary spending to deviations of the debt-to-GDP ratio from its sample average for the full sample. In the first sub-sample (1979:1 - 1993:3), there is some evidence suggesting a weak stabilizing effect that works mainly through government spending: when the debtto-GDP ratio is above its historical mean, government primary spending decreases (the coefficient associated to $\left(d_{t^{-1}}-d^{*}\right)$ is negative $(-0.005)$, although some destabilizing effect then also occurs via the revenue side. In the second sub-sample (1993:4 2007:4), the empirical findings show that government revenue plays some stabilizing effect: when the debt-to-GDP ratio is above its historical mean, government revenue increases as the coefficient associated to $\left(d_{t-1}-d^{*}\right)$ is positive $(0.006)$.

Therefore, we can conclude that when faced with high government indebtedness and fiscal imbalances in the Maastricht sub-period, the fiscal stabilization responses have been biased towards increases in government revenue. 


\subsection{A VAR counter-factual exercise}

We now conduct a VAR counter-factual exercise aimed at describing the effects of shutting down the shocks in government spending or government revenue. In practice, after estimating the VAR summarized by (1), (2) and (3), we construct the counter-factual $(C F T)$ series as follows:

$$
\begin{gathered}
\underbrace{\Gamma(L) \underbrace{X_{t}^{C F T}}_{n \times 1}+\gamma_{i} d_{t-1}=}_{n \times n} \Gamma_{0} X_{t}{ }^{C F T}+\Gamma_{1} X_{t-1}{ }^{C F T}+\ldots+\gamma_{i} d_{t-1}=c+\varepsilon_{t}{ }^{C F T} \\
d_{t}=\frac{1+i_{t}}{\left(1+\pi_{t}\right)\left(1+\mu_{t}\right)} d_{t-1}+\frac{G_{t}-T_{t}}{P_{t} Y_{t}} \\
v_{t}{ }^{C F T}=\Gamma_{0}{ }^{-1} \varepsilon_{\mathrm{t}}{ }^{\mathrm{CFT}} .
\end{gathered}
$$

This is equivalent to consider the following vector of structural shocks

$$
\begin{aligned}
& \varepsilon_{t}^{C F T}=\left[0, \varepsilon_{t}^{T}, \varepsilon_{t}{ }^{Y}, \varepsilon_{t}{ }^{P}, \varepsilon_{t}^{i}, \varepsilon_{t}{ }^{I}, \varepsilon_{t}{ }^{C}\right]^{\prime} \\
& \varepsilon_{t}{ }^{C F T}=\left[\varepsilon_{t}{ }^{G}, 0, \varepsilon_{t}{ }^{Y}, \varepsilon_{t}{ }^{P}, \varepsilon_{t}{ }^{i}, \varepsilon_{t}{ }^{I}, \varepsilon_{t}{ }^{C}\right]
\end{aligned}
$$

where we shut down, respectively in (13) and in (14), the government primary spending and the government revenue unexpected variation and then use the counter-factual structural shocks to build the counter-factual series for all endogenous variables of the system.

This empirical exercise allows us to quantify the magnitude of fiscal policy shocks and its impact on a set of macroeconomic variables. Moreover, it helps us understanding what the dynamics of the economy would be in the absence of unexpected variation in fiscal policy.

Figure 6a plots the actual and the counter-factual series for GDP, private consumption, private investment, and government spending in the case of a shock to government spending. Figure $6 \mathrm{~b}$ displays the actual and the counter-factual series for 
GDP, private consumption, private investment, and government revenue in the case of a shock to government revenue.

\section{[Figure 6]}

The results show that fiscal policy shocks play a minor role as the difference between the actual and the counterfactual series are relatively small. Nevertheless, one can see that in the absence of government spending shocks, private consumption and private investment would have been higher, for instance, in the period 1983-1988 and, more recently, since 2003. Therefore, such evidence suggests and confirms that unexpected increases in government spending generate relevant "crowding-out" effects, a useful insight to bear in mind when resorting to fiscal instruments to boost the economy.

In the case of government revenue, the difference between the actual and the counterfactual series are negligible, a feature that may be related with the relative size of the government revenue shocks. In fact, while unexpected variation in government spending seems to be large - as follows from the larger differences between the actual government spending and the counter-factual government spending -, government revenue shocks are generally small.

\section{Conclusion}

This paper evaluates the macroeconomic effects of fiscal policy in Portugal for the period 1979:1-2007:4, drawing on a new set of quarterly data built from the monthly Central Government's cash data. We identify fiscal policy shocks using: (i) a recursive partial scheme, and estimate a Bayesian Structural Vector Autoregression; and (ii) a Fully Simultaneous System approach, where we account for the automatic response of fiscal policy to the economic activity. Consequently, the use of such high frequency 
fiscal data, which is quite valuable from a perspective of monitoring the fiscal position, turns out to be also rather useful from a modelling point of view.

The empirical evidence suggests that government spending shocks: (i) have, in general, a negative effect on GDP; (ii) lead to a fall of both private consumption and private investment; (iii) rise persistently and positively the price level; and (iv) have mixed effects on the average cost of refinancing the debt. More specifically, a $1 \%$ positive shock in government spending has a maximum impact on GDP of $-0.1 \%$, while "crowding-out" both private consumption and private investment, which fall by $0.12 \%$ and $0.2 \%$, respectively.

In addition, government revenue shocks have a negative impact on GDP, on private consumption and on private investment, although the response emerges with a lag of about four quarters. In fact, at this horizon, a $1 \%$ positive shock in government revenue is able to generate a positive response of GDP by $0.06 \%$, and an increase of both private consumption and private investment of $0.04 \%$ and $0.14 \%$, respectively. After this, the macroeconomic effects of the tax shock erode and even become negative.

These results suggest that an expansion of government spending is associated to an episode of fiscal deterioration. Similarly, an increase in government revenue is followed by a somewhat less disciplined fiscal policy. This helps explaining the different reaction of the cost of debt to the fiscal policy shock across the two identification methods. Nevetheless, the response of the other macroeconomic variables included in the different frameworks is qualitative and quantitative similar, which gives support to the policy implications of the paper and allows us to be confident on the correct identification of the unexpected variation in fiscal policy.

When we explicitly consider the feedback from government debt, (long-term) interest rates become more responsive, GDP is marginally less responsive, and the 
effects of fiscal policy on these variables also become more persistent. In addition, the results provide weak evidence of stabilizing effects of the debt level on the primary budget balance.

In a nutshell, it is adequate to say that the results reinforce the idea that fiscal behaviour in Portugal came short of effectively consolidating public finances. Moreover, expansionary spending shocks have tended to lower real GDP growth. In addition, a VAR counter-factual exercise shows that unexpected spending shocks are responsible for important "crowding-out" effects.

Therefore, the current study provides relevant policy implications, notably from the perspective of the fiscal authorities. Most important is the fact that expansionary fiscal policies in Portugal do not emerge as an obvious instrument to foster economic growth. On the other hand, and from an inflation control point of view, government spending also puts upwards pressure on the price level.

Another significant result, to bear in mind by policymakers when implementing fiscal policy measures in a small open economy as Portugal, is the fact that when faced with high government indebtedness and fiscal imbalances, after the Maastricht Treaty entered into force, the fiscal stabilization responses have been biased towards increases in government revenue. Given the associated excess burden of taxation of such policies and the uncovered crowding-out effect of government spending, it would be advisable to consider designing fiscal policies from a perspective of reducing total government spending. Such approach, when pursued in good times, would contribute to consolidate public finances in a more sustained fashion, while allowing more leeway for an expansionary behaviour in crises, and still within the EU fiscal framework. 


\section{References}

Afonso, A. (2010), "Expansionary fiscal consolidations in Europe: new evidence", Applied Economics Letters, 17 (2), 105-109.

Afonso, A., and P. Claeys (2008), "The dynamic behaviour of budget components and output”, Economic Modelling, 25, 93-117.

Afonso, A., and S. Fernandes (2008). "Assessing hospital efficiency: non-parametric evidence for Portugal", Department of Economics, ISEG-UTL, Working Paper $\mathrm{N}^{\circ}$. 07/2008/DE/UECE.

Afonso, A., and R. M. Sousa (2009a), "The macroeconomic effects of fiscal policy", ECB Working Paper No. 991.

Afonso, A., and R. M. Sousa (2009b), "Fiscal policy, housing and stock prices", ECB Working Paper $N^{\circ} .990$.

Alesina A., and S. Ardagna (1998), "Tales of fiscal adjustment”, Economic Policy, 27, 489-545.

Beetsma, R., and H. Jensen (2005), "Monetary and fiscal policy interactions in a MicroFounded Model of a Monetary Union”, Journal of International Economics, 67, 320352.

Biau, O., and E. Girard (2005), "Politique budgétaire et dynamique économique en France: l'approche VAR structurel.”, Économie et Prévision, 169-171, 1-24.

Blanchard, O. (2007), “Adjustment within the Euro: The Difficult Case of Portugal”, Portuguese Economic Journal, 6(1), 1-21.

Blanchard, O., and R. Perotti (2002), "An empirical characterization of the dynamic effects of changes in government spending and taxes on output", Quarterly Journal of Economics, 117(4), 1329-1368.

Bohn, H. (1998), "The Behaviour of U.S. public debt and deficits", Quarterly Journal of Economics, 113, 949-963.

Burriel, P., de Castro, F., Garrote, D., Gordo, E., Paredes, J. and Pérez, J. (2010). "Fiscal policy shocks in the euro area and the US: An empirical assessment", Fiscal Studies, 31(2), 251-285.

Christiano, L. J., Eichenbaum, M., and C. L. Evans (2005), "Nominal rigidities and the dynamic effects of a shock to monetary policy", Journal of Political Economy, $113(1), 1-45$. 
De Castro Fernández, F., and P. Hernández De Cos (2008), "The economic effects of exogenous fiscal shocks in Spain: a SVAR approach", Journal of Macroeconomics, $30,1005-1028$.

Fatás, A., and I. Mihov (2001), "The effects of fiscal policy on consumption and employment: theory and evidence", CEPR Discussion Paper Nº 2760.

Favero, C., and F. Giavazzi (2007), "Debt and the effects of fiscal policy", University of Bocconi, Working Paper No. 317.

Giavazzi, F., and M. Pagano (1990), "Can severe fiscal contractions be expansionary? Tales of two small european countries", in Blanchard, O. J.; Fischer, S. (eds.), NBER Macroeconomics Annual, MIT Press, 75-110.

Giavazzi, F., Jappelli, T., and M. Pagano (2000), "Searching for non-linear effects of fiscal policy: evidence from industrial and developing countries", European Economic Review, 44(7), 1259-1289.

Giordano, R., Momigliano, S., Neri, S., and R. Perotti (2007), "The effects of fiscal policy in Italy: Evidence from a VAR model", European Journal of Political Economy, 23, 707-733.

Girouard, N., and C. André (2005), "Measuring cyclically-adjusted budget balances for OECD countries”, OECD Economics Department Working Paper No. 434.

Guichard, S., and W. Leibfritz (2006). "The fiscal challenge in Portugal", OECD Working Paper $\mathrm{N}^{\circ} .489$.

Heppke-Falk, K. H., Tenhofen, J., and G. B. Wolff (2006), “The macroeconomic effects of exogenous fiscal policy shocks in Germany: a disaggregated SVAR analysis", Deutsche Bundesbank, Discussion Paper Nº 41.

Leeper, E. M., and T. Zha (2003), "Modest policy interventions”, Journal of Monetary Economics, 50(8), 1673-1700.

Mountford, A., and H. Uhlig (2009), "What are the effects of fiscal policy shocks?", Journal of Applied Econometrics, 24 (6), 960-992.

Perotti, R. (1999), "Fiscal policy in good times and bad", Quarterly Journal of Economics, 114, 1399-1436.

Perotti, R. (2004), "Estimating the effects of fiscal policy in OECD countries", Bocconi University, IGIER Working Paper Nº. 276.

Pina, A. (2004), "Fiscal policy in Portugal: discipline, cyclicality and the scope for expenditure rules", proceedings of the $2^{\text {nd }}$ Conference on Portuguese Economic 
Development in the European Context, held by the Bank of Portugal in Lisbon, 1112 March 2004, 15-65.

Ramey, V., and M. Shapiro (1998), "Costly capital reallocation and the effects of government spending", Carnegie Rochester Conference on Public Policy, 48, 145194.

Romer, C., and D. H. Romer (2007), "The macroeconomic effects of tax changes: estimates based on a new measure of fiscal shocks", American Economic Review, 100(3), 763-801.

Sims, C., and T. Zha (2006), "Does monetary policy generate recessions?", Macroeconomic Dynamics, 10(2), 231-272.

Sims, C., and T. Zha (1999), "Error bands for impulse-responses", Econometrica, 67(5), 1113-1155. 


\section{Appendix - Data description and sources}

GDP

Data for GDP are quarterly, seasonally adjusted, and comprise the period 1978:12007:4. The source is the Bank of Portugal.

Private Consumption

The source is the Bank of Portugal. Consumption is defined as the household consumption expenditure including non-profitable institutions serving households. Data are quarterly, seasonally adjusted, and comprise the period 1978:1-2007:4.

Price Deflator

All variables were deflated by the GDP deflator $(2000=100)$. Data are quarterly, seasonally adjusted, and comprise the period 1978:1-2007:4. The source is the Bank of Portugal.

Private Investment

The source is the Bank of Portugal. Private Investment is defined as total gross fixed capital formation. Data are quarterly, seasonally adjusted, and comprise the period 1978:1-2007:4.

Government Spending

The source is the Bank of Portugal, collected from the Monthly Bulletin of the Directorate-General of Public Accounting. Government Spending is defined as Central Government primary spending (on a cash basis), that is, the difference between authorized expenditure and debt interest payments. We seasonally adjust quarterly data using Census X12 ARIMA, and the series comprise the period 1978:1-2007:4.

Interest Payments

The source is the Bank of Portugal, collected from the Monthly Bulletin of the Directorate-General of Public Accounting. Interest Payments is defined as Central Government debt interest payments (on a cash basis). We seasonally adjust quarterly data using Census X12 ARIMA, and the series comprise the period 1978:1-2007:4.

Government Revenue

The source is the Bank of Portugal, collected from the Monthly Bulletin of the Directorate-General of Public Accounting. Government Revenue is defined as Central Government total revenue (on a cash basis). We seasonally adjust quarterly data using Census X12 ARIMA, and the series comprise the period 1978:1-2007:4.

Government Debt

The source is the Bank of Portugal, the Directorate-General of Treasury, and the Directorate-General of Public Credit. Government Debt is defined as the stock of Direct State Debt.

The original series are available as follows:

1.

a) Total Internal Debt, for the period 1997:12-1994:6, on a quarterly basis;

b) Internal Direct Debt, for the period 1997:12-1994:6, on a quarterly basis;

c) Total External Debt, for the period 1997:12-1994:6, on a quarterly basis;

d) Direct External Debt, for the period 1997:12-1994:6, on a quarterly basis; 
e) Total Public Debt, for the period 1997:12-1994:6, on a quarterly basis;

2 .

f) Effective Public Debt, for the period 1997:12-1994:6, on a quarterly basis;

a) Internal Effective Direct Debt, for the periods 1991:12, 1992:12, and 1993:61995:11, on a monthly basis;

b) Total Effective Direct Debt, for the periods 1991:12, 1992:12, and 1993:61995:11, on a monthly basis

3.

a) Internal Direct Debt, for the period 1995:7-1998:12, on a monthly basis;

b) Total Direct Debt, for the period 1995:7-1998:12, on a monthly basis 4.

a) Direct State Debt, for the period 1998:12-2007:4, on a monthly basis.

We build the series for the Direct State Debt as follows:

1) For the period 1998:12-2008:4, as the series of Direct State Debt itself;

2) For the period 1995:7-1997:12, we use the ratio of Direct State Debt to Total State Debt in 1998:12 (that is, a scale factor of 0.994679113), to back-out the series of Direct State Debt;

3) For the period 1993:6-1995:6, we use the ratio of Total Effective Direct State Debt to Total Direct State Debt in the period 1995:7-1995:11 (that is, a scale factor of 1.002277388), to back-out the series of Total Direct Debt;

4) For the period 1977:12-1993:3, we use the ratio of (Effective Public Debt minus Non-Direct Debt) to Total Effective Direct Debt in the period 1993:6-1994:6 (that is, a scale factor of 1.03997385), to back-out the series of Total Effective Direct Debt.

Given that the scale factors are very close to one, the time series of the Direct State Debt is smooth over time and we guarantee that there are not structural breaks.

We build the quarterly series using monthly data (where available) and seasonally adjust it using Census X12 ARIMA. The constructed series comprise the period 1977:42007:4.

Average Cost of Financing Debt

The average cost of financing debt is obtained by dividing interest payments by debt at time $t-1$.

Long-Term Interest Rate

Long-Term Interest Rate corresponds to the yield to maturity of 10-year government securities. Data are quarterly, and comprise the period 1957:1-2007:4. Data for the period 1974:2-1975:4 is not available. Therefore, we linearly interpolate the data for that period using the observations at 1974:1 and 1976:1. The source is the IMF, International Financial Statistics (series " IFS.Q.182.6.61.\$\$\$.Z.F.\$\$"). 
Figure 1 - Monetary conditions and fiscal balances in Portugal (2000-2008).

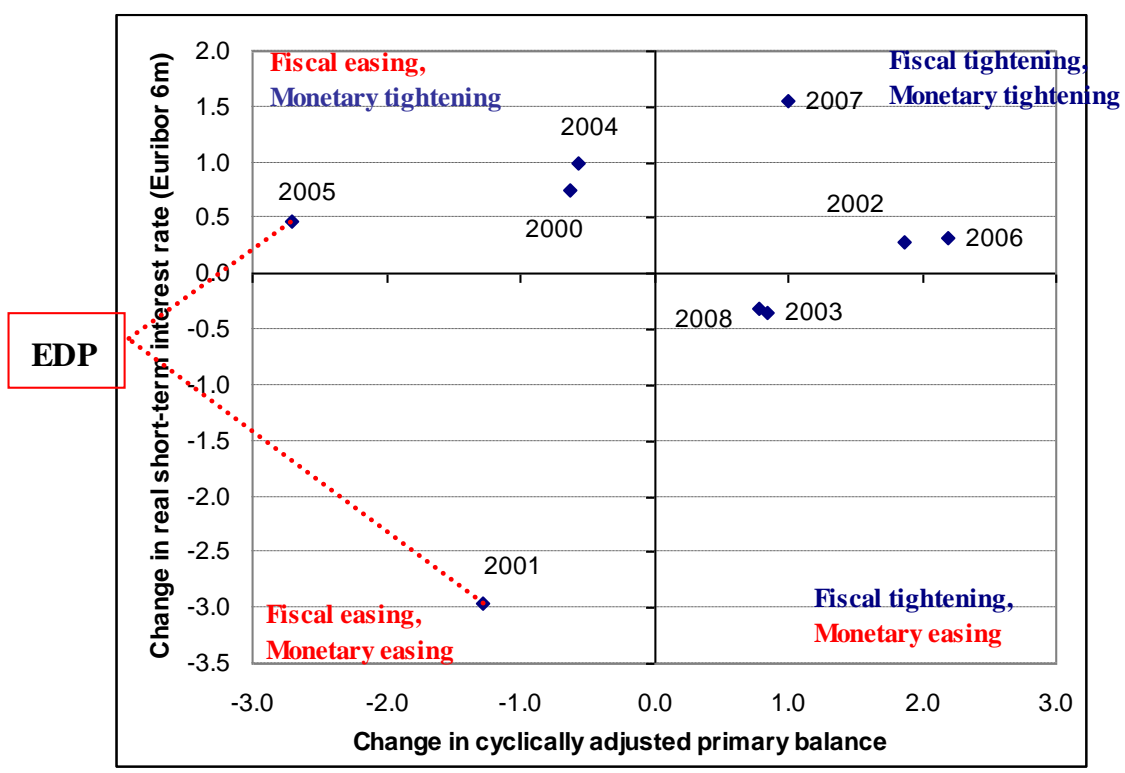

Source: EC, Eurostat, Banco de Portugal, and own calculations.

Notes: HICP, September 2008, Euribor, October 2008, and EC Autumn 2008 forecasts for CAPB in 2008. EDP - Excessive Deficit Procedure.

Figure 2 - Average cost of servicing debt and (annualized) nominal GDP growth.

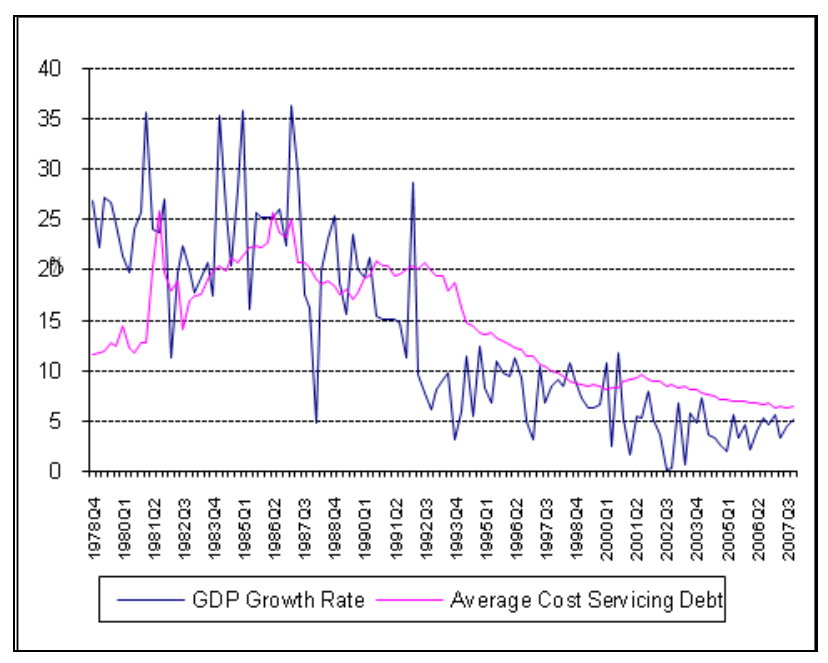

Figure 3 - Implicit debt ratio and observed debt ratio, percentage of GDP.

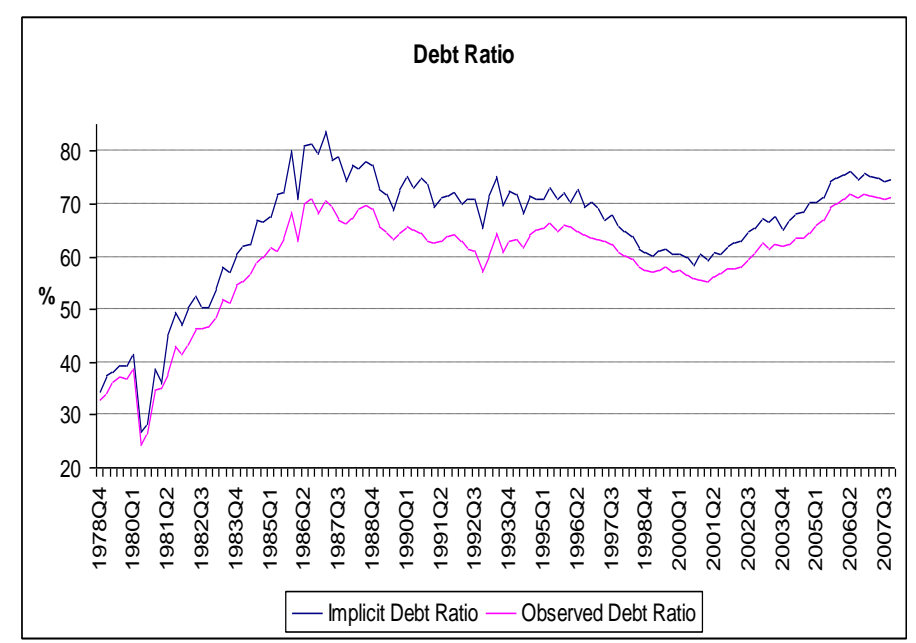

Note: Implicit debt ratio computed via equation (9). 
Figure 4 - Impulse-response functions: the Bayesian Structural VAR. $4 \mathrm{a}$ - spending shock
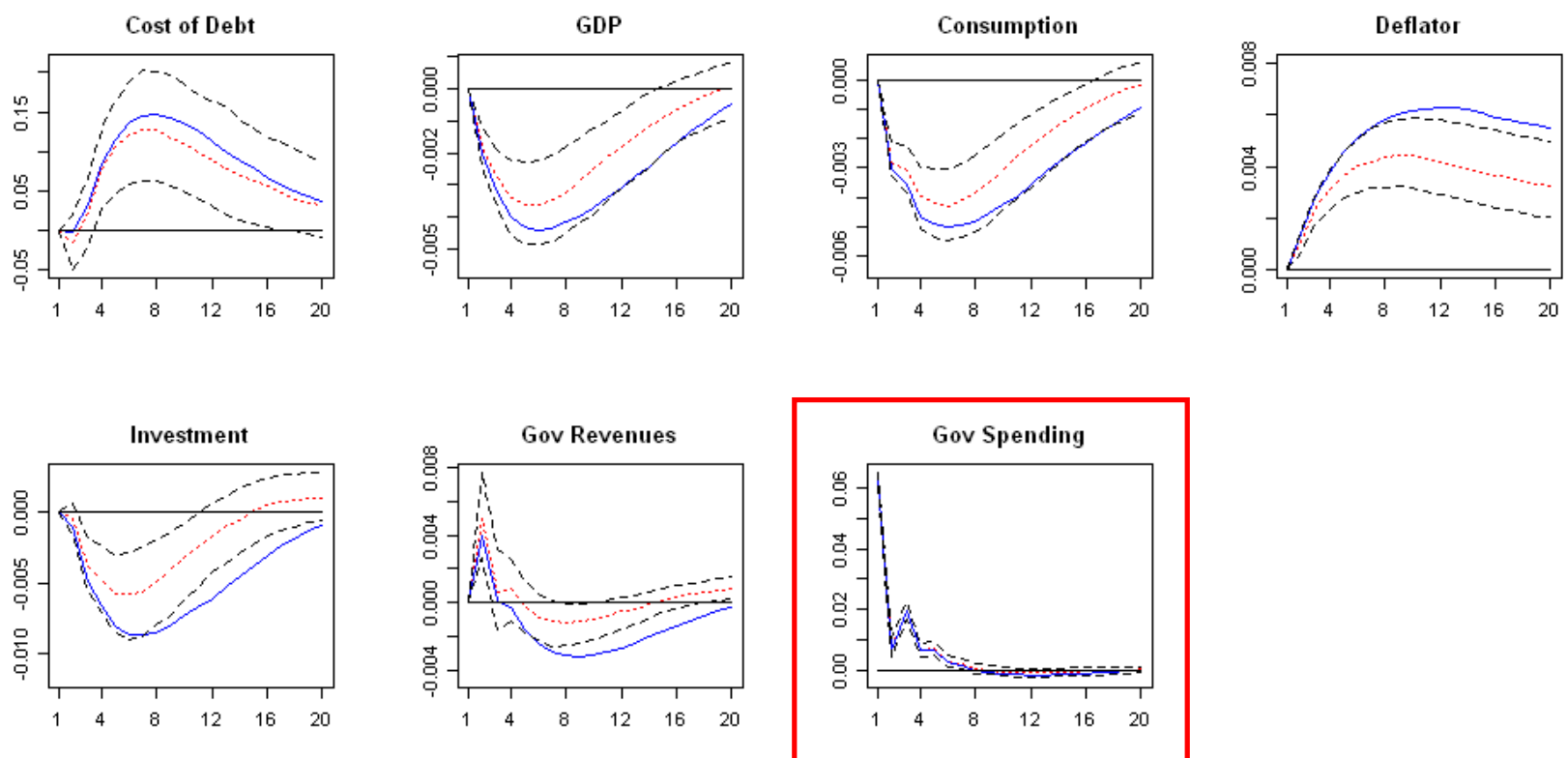

$4 b-$ revenue shock
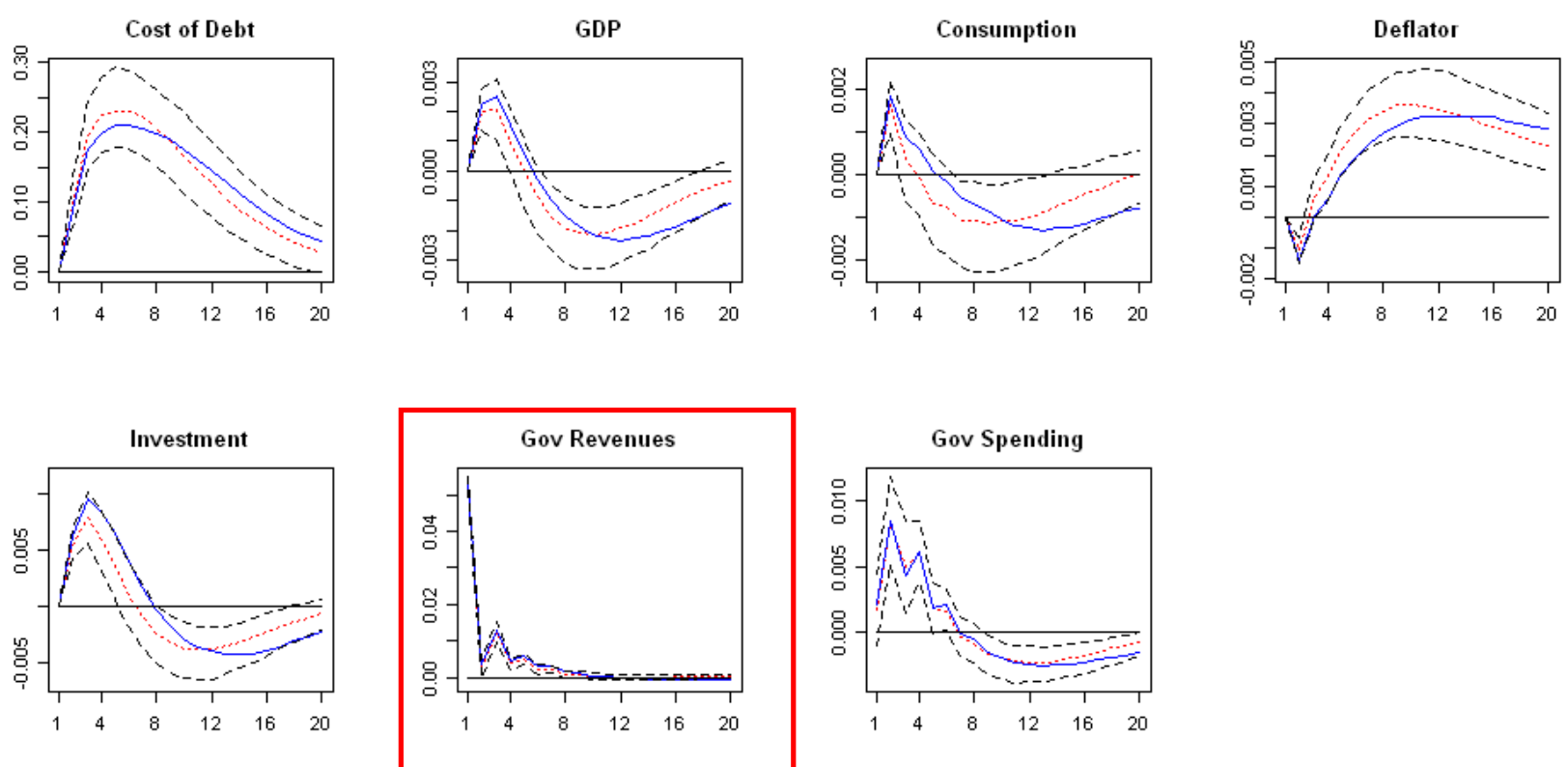

Notes: The solid line corresponds to the median estimate when the model is estimated without accounting for the feedback from government debt; the dotted line corresponds to the median estimate and the dashed lines indicate the 68 per cent posterior confidence intervals estimated by using an Importance Sampling Normalized Weights algorithm based on 50000 draws, when the debt dynamics is included in the model. 
Figure 5 - Impulse-response functions: the Fully Simultaneous System approach. $5 \mathrm{a}$ - spending shock
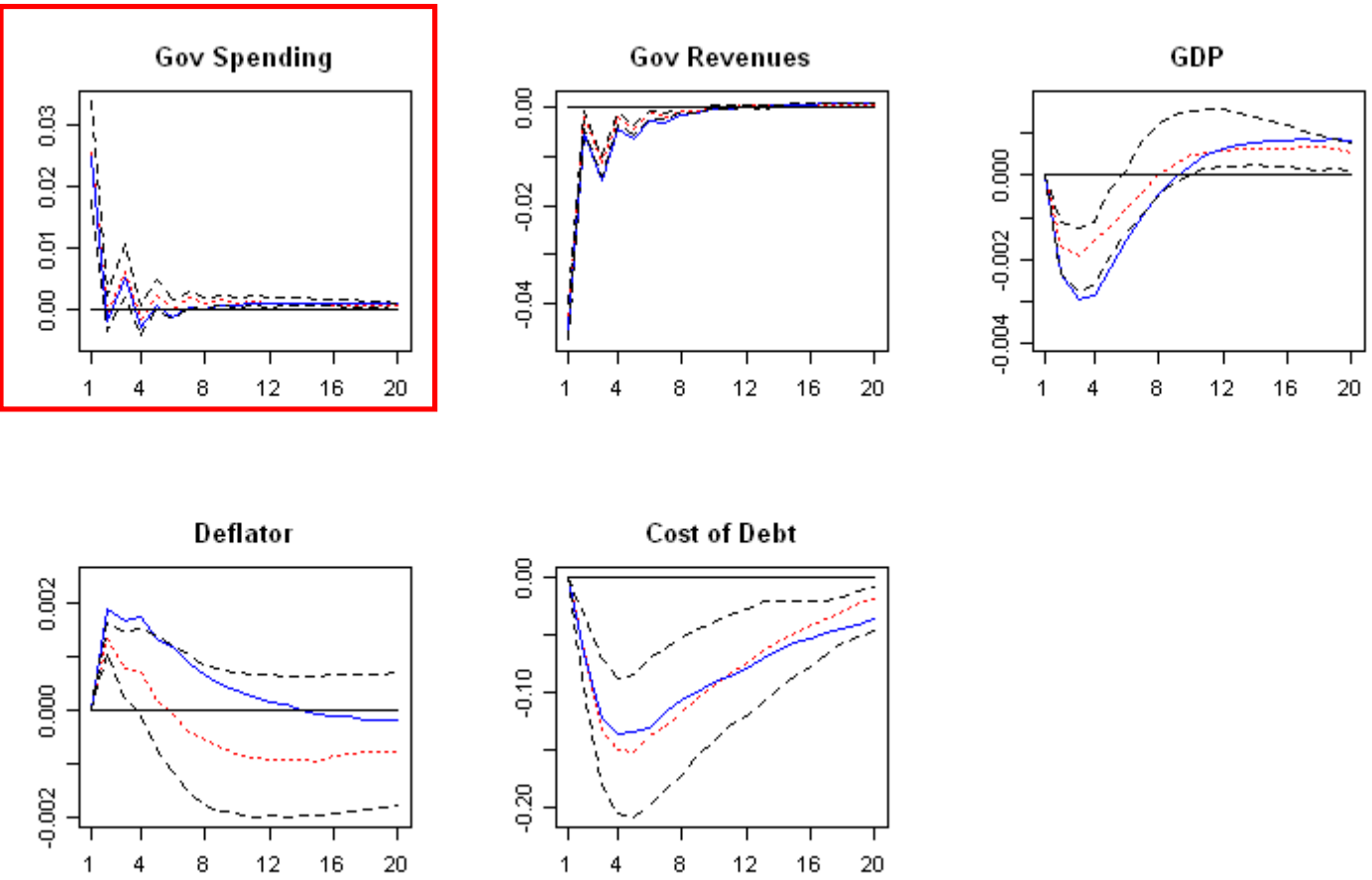

\section{$5 b$ - revenue shock}
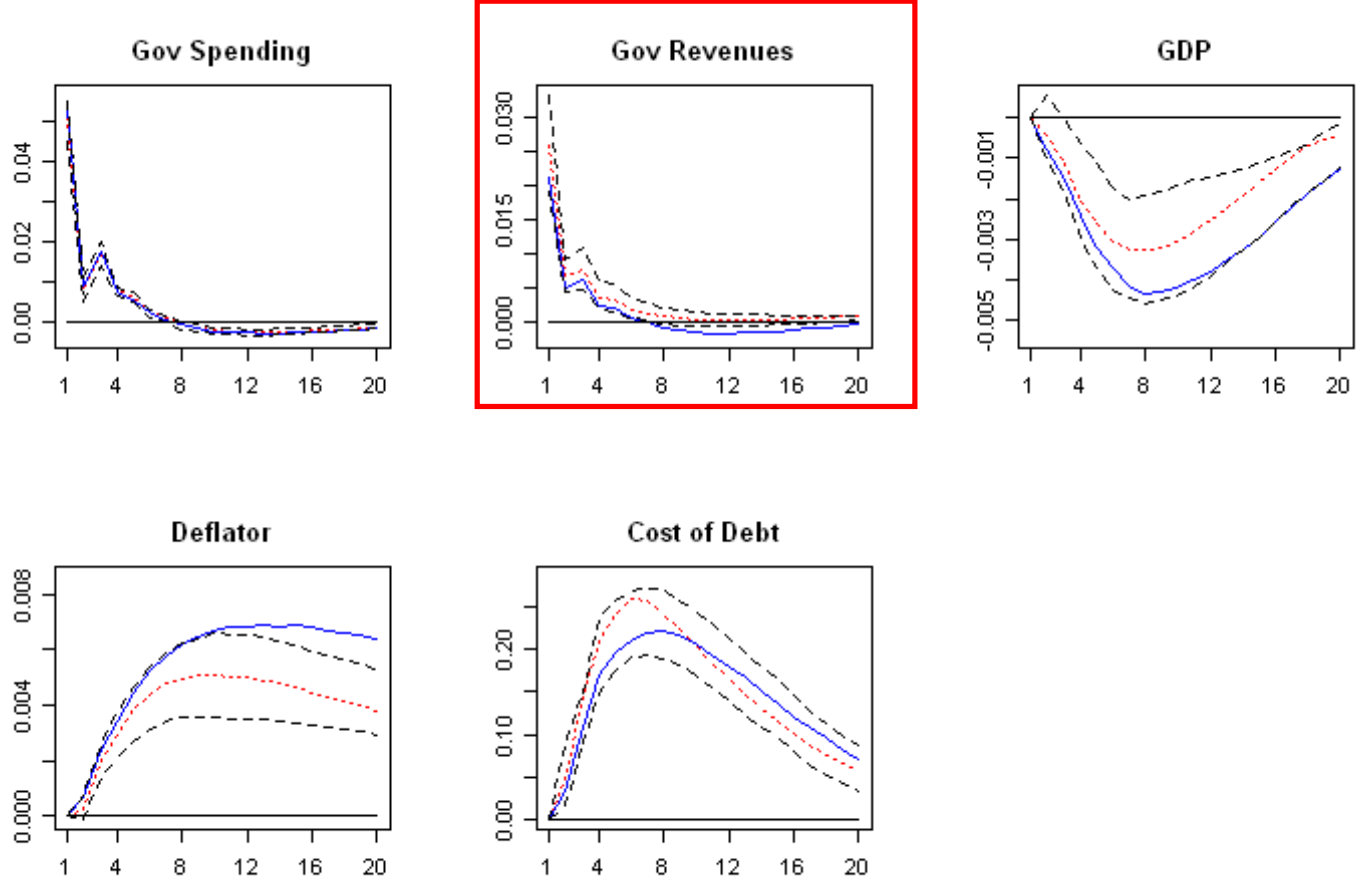

Notes: The solid line corresponds to the median estimate when the model is estimated without accounting for the feedback from government debt; the dotted line corresponds to the median estimate and the dashed lines indicate the 68 per cent posterior confidence intervals estimated by using an Importance Sampling Normalized Weights algorithm based on 50000 draws, when the debt dynamics is included in the model. 
Figure 6 -VAR counterfactual.

$6 \mathrm{a}-$ spending shock
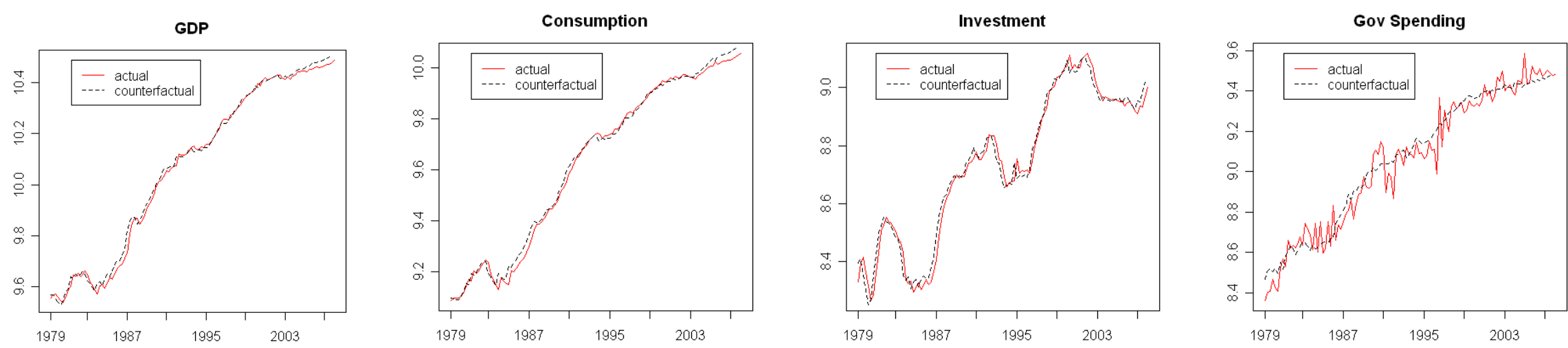

$6 b-$ revenue shock
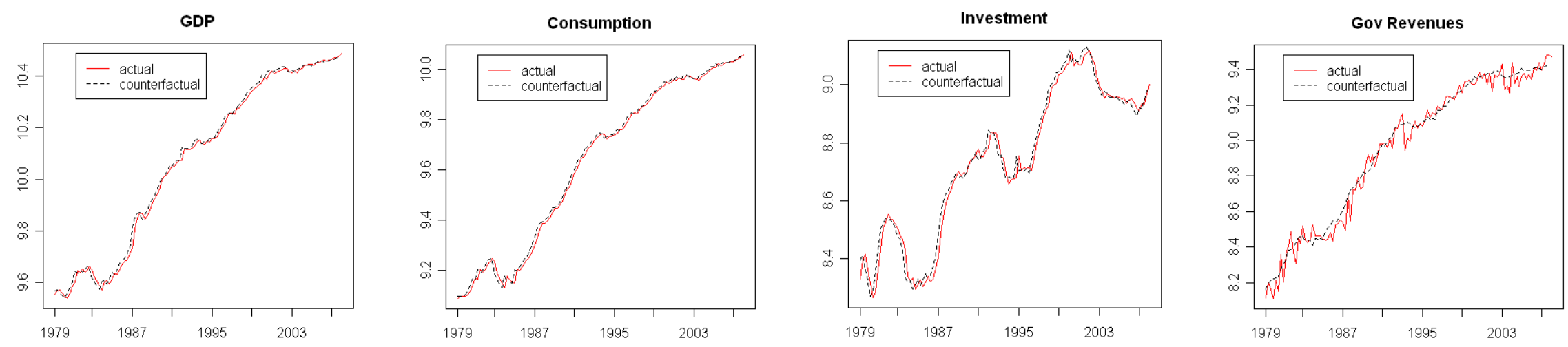

Note: All series are in logs of real terms. 